\title{
ANALISIS IMPLEMENTASI PEMUNGUTAN PAJAK KENDARAAN BERMOTOR (PKB) PADA KANTOR UPTD WILAYAH 1 SAMSAT BANDAR LAMPUNG
}

\author{
Agustuti Handayani $^{1}$, Cindy Damayanti Hendarly ${ }^{2}$ \\ Ilmu Administrasi publik, Fakultas Ilmu Sosial dan PolitikUniversitas Bandar Lampung, \\ Zainal Abidin Pagar Alam Nomor 26, Labuhan Ratu, Kedaton, 35142, \\ Bandar Lampung, Indonesia \\ E-mail: \\ agustuti.handayani@ubl.ac.id \\ cindy.17111068@student.ubl.ac.id
}

\begin{abstract}
SAMSAT is a public service management system that will be carried out with three government agencies in the same building, this system is designed to accelerate activities (namely public services), so that these services are stored in one building. This one-stop cooperation involves several government agencies, including the National Police, the Regional Revenue Agency, and PT JasaRaharja (Persero). The National Police has the function of issuing STNK, local taxes to determine the amount of Motor Vehicle Tax (PKB) and Transfer of Motor Vehicle Title Fee (BBN-KB), as well as PT JasaRaharja, which applies a mandatory traffic accident fee (SWDKLLJ). The purpose of this research is to find out how the implementation of motor vehicle tax collection policies and the factors that influence the implementation of PKB policies. This type of research is descriptive qualitative research and in this study the authors also use the theory of policy implementation from Edward III. This theory uses 4 aspects, namely communication, resources, disposition, and bureaucratic structure. The research technique was carried out by interview, observation, and documentation in UPTD Region 1 SAMSAT Bandar Lampung. The results of this study reveal that the implementation of this policy has been quite effective. Then in this study there are supporting factors such as Adequate Human Resources. To meet this need, employees need to be equipped with the ability and professionalism to provide high-quality services based on the concept of human resource management or take advantage of complaints from the public about PKB payment services for them. And for the factors that hinder it due to public awareness of timely tax payments. Based on the results of this study, it is suggested that: It is mandatory to build awareness among all taxpayers who are disciplined in carrying out their tax obligations and tax officers who have more control over taxpayers who have never received disciplinary action in carrying out their tax obligations.
\end{abstract}

Key words: Analysis of Policy Implementation, Collecting PKB 


\begin{abstract}
ABSTRAK
Sistem Administrasi Manunggal Satu Atap (SAMSAT) ialah sistem manajemen pelayanan publik akan dilakukan dengan tiga instansi pemerintah dalam satu gedung yang sama, sistem ini dirancang untuk mempercepat kegiatan (yaitu pelayanan publik), sehingga pelayanan tersebut disimpan di dalam satu gedung. Kerja sama satu pintu ini melibatkan beberapa suatu instansi pemerintah, antara lain Polri, Badan Pendapatan Daerah, dan PT Jasa Raharja (Persero). Polri memiliki fungsi menerbitkan STNK, pajak daerah menetapkan besaran Pajak Kendaraan Bermotor (PKB) dan Bea Balik Nama Kendaraan Bermotor (BBN-KB), serta PT Jasa Raharja yang mengurus iuran wajib dana kecelakaan lalu lintas (SWDKLLJ). Tujuan penelitian ini ialah mencari tahu bagaimana implementasi kebijakan pemungutan pajak kendaraan bermotor dan mengetahui faktor-faktor yang mempengaruhi suatu implementasi kebijakan PKB.Jenis penilitian ini merupakan penelitian kualitatif deskriptif dan dalam penelitian ini juga penulis menggunakan teori implementasi kebijakan dari Edward III. Teori ini menggunakan 4 aspek yaitu komunikasi, sumber daya, disposisi, struktur birokrasi. teknik penelitian dilakukan dengan wawancara, observasi, dan dokumentasi di UPTD Wilayah 1 SAMSAT Bandar Lampung.Hasil penelitian ini adalah mengungkapkan bahwa mekanisme pelaksanaan kebijakan ini sudah cukup efektiflalu didalam penelitianini adanya faktor yang mendukung seperti Sumber Daya Manusia yang Cukup Memadai. Untuk memenuhi kebutuhan ini, karyawan perlu dibekali dengan kemampuan dan profesionalisme untuk memberikan layanan berkualitas tinggi berdasarkan konsepsi manajemen sumber daya manusia atau memanfaatkan keluhan dari masyarakat tentang layanan pembayaran PKB bagi mereka. Dan untuk faktor yang menghambatnya ialah kurangnya kesadaran masyarakat akan pembayaran pajak kendaraan bermotor tepat waktu. Berdasarkan hasil penelitian ini peneliti menyarankan: Wajib dibangunnya kesadaran di antara semua wajib pajak supaya dapat disiplin dalam melakukan atau melaksanakan kewajiban perpajakannya danPetugas pajak supaya memiliki kontrol yang lebih terhadap Wajib Pajak yang tidak pernah mendapat tindakan disiplin dalam melaksanakan kewajiban perpajakannya.
\end{abstract}

kata kunci : Analisis Implementasi Kebijakan, Pemungutan PKB 


\section{PENDAHULUAN}

Pengelolaan pajak kendaraan bermotor suatu kewajiban untuk itu harus dilakukan oleh pemilik kendaraan bermotor. Misalnya, verifikasi ulang STNK tahunan dan penggantian STNK lima tahun sangat penting bagi pengemudi kendaraan bermotor. Apakah verifikasi STNK terkait dengan validitas / efektifitas STNK. Jika STNK yang Anda miliki sudah habis masa berlakunya, Anda dapat dikenakan sanksi oleh pengemudi kendaraan bermotor. dengan ini sejalan dengan Pasal 68 Undang-Undang Nomor 22 Tahun 2009 tentang lalu lintas dan angkutan jalan mengatur bahwa setiap kendaraan bermotor akan melaju di jalan raya harus di lengkapi dengan Surat Tanda Nomor Kendaraan (STNK) dan Tanda Pengenal Kendaraan Bermotor (TNKB).

Sistem Administrasi Manunggal Satu Atap (Samsat) ialah salah satu instansi pemerintah siapa yang akan menyediakan pelayanan terkait pembayaran wajib pajak kendaraan bermotor. Samsat Bandar Lampung menyediakan layanan manajemen untuk masyarakat wajib pajak terkait pengurusan (1) Bea Balik Nama Kendaraan Bermotor (BBNKB). Bentuk layanan ini adalah untuk menangani pajak atas kendaraan beroda dua atau beroda empat (mobil) baru demikian pula untuk mengatur perubahan kepemilikan kendaraan yang disebabkan oleh proses jual beli. (2) Pajak Kendaraan Bermotor (PKB). Layanan ini untuk keringanan pajak tahunan untuk kendaraan roda dua dan empat (mobil) rutin setahun sekali.

Sebagai salah satunya instansi pemerintah yang akan memberikan pelayanan perpajakan kepada masyarakat wajib pajak, SAMSAT belum lepas dari berbagainya masalah terkait penyelenggaraannya pelayanan publik. ada Beberapa masalah yang sering terjadi dengan SAMSAT meliputi Tuntutannya masyarakat akan peningkatan pelayanan dalam kaitanya integritas kendaraan (termasuk pengelolaan fisik dan administrasi) semakin mudah dan cepat karena mobilitas lalu lintas masyarakat yang cukup tinggi. Tujuan dalam implementasi pemungutan pajak kendaraan bermotor ini memberikan suatu pelayanan semaksimal mungkin kepada para wajib pajak dengan cara seperti mensosialisasikan kebijakan pajak daerah tersebut pada saat implementasi. Dan memberikan akses pelayanan yang sangat luas seperti akses melalui samsat link, samsat keliling dan samsat drive thru dalam bentuk sebagai sebuah pelayanan publik

\section{TINJAUAN PUSTAKA}

Kebijakan Publik

Dunn (William N. Dunn, 1999), bahwa Kebijakan Publik adalah model kompleks yang bergantung pada pilihan bersamasama untuk saling ketergantungan, termasuk keputusan yang tidak diambil kepada lembaga atau kantor pemerintah. Kebijakan publik ini yang diajukan kepada Dunn menyiratkan bahwa terdapat pilihan bersama yang bergantung satu sama lain, dan tindakan diambil dalam pilihan kolektif ini. Kebijakan publik yang diharapkan dirumuskan kepada badan atau kantor pemerintah. Jika suatu kebijakan dirumuskan, maka harus dilaksanakan dan dievaluasi oleh departemen administrasi yang menggerakkan keuangan dan sumber daya manusia agar dapat digunakan sebagai suatu mekanisme pengawasan kebijakan ini sesuai dengan tujuan apa itu kebijakan itu sendiri.

\section{Implementasi Kebijakan}

Nugroho (Andhini, 2017), bahwa implementasi kebijakan merupakan suatu tindakan, sehingga suatu kebijakan dapat mencapai tujuannya. Untuk melaksanakan kebijakan publik terdapat dua pilihan yaitu berupa rencana atau melalui formulasi kebijakan turunan atau bentuk turunan kebijakan publik.Sedangkan menurut Tangkilisan (Rushananto, 2014), implementasi atau pelaksanaan ini terkait 
dalam berbagai kegiatan bertujuan untuk merealisasikan rencana, dalam hal ini penyelenggara mengatur cara menata, menafsirkan, dan melaksanakan kebijakannya untuk dipilih. Rencana dan / atau kebijakan yang dianggap sebagai solusi alternatif untuk masalah harus dilaksanakan oleh instansi administrasi tingkat bawah dan instansi pemerintah.Staf administrasi dapat secara efektif mengelola sumber daya, unit dan teknologi yang dapat mendukung pelaksanaan rencana, dan menjelaskan rencana dan prosedur yang diselesaikan, dan instruksi yang mudah diterapkan.

\section{Konsep Pajak}

konsep pajak menurut Menurut Andriani dalam waluyo(puji rahayu, SE, 2019),pajak ialah negara yang harus membayar pajak nasional (dapat ditegakkan), orang-orang ini wajib membayar yang belum dibayar sesuai ketentuan, dan dapat langsung menunjuk dan menggunakan Pengeluaran terkait dengan negara Pengeluaran umum terkait dengan tugas-tugas pemerintah.

\section{Pajak Kendaraan Bermotor (PKB) \\ Menurut Undang-Undang Nomor} 28 Tahun 2009, Pajak Kendaraan Bermotor adalah pajak yang dikenakan atas kepemilikan dan / atau penguasaan kendaraan bermotor. Saat pengumpulan dilakukan, akan dilakukan di kantor bersama Samsat. Kantor bersama SAMSAT terdiri dari tiga instansi pemerintah, yaitu: Dinas Pendapatan Daerah, Polri dan PT. (Persero) Asuransi kerugian Jasa Raharja. Yang dimaksud dengan kendaraan bermotor adalah semua kendaraan bermotor roda dua atau lebih sepeda motor beserta gandengannya.Semua jenis jalan darat menggunakan kendaraan bermotor ini, yang digerakkan dalam bentuk alat-alat teknis berupa sepeda motor atau perlengkapan lainnya, Alat tersebut atau peralatan dapat mengubah sejumlah energi menjadi tenaga penggerak kendaraan bermotor terkait, termasuk alat berat dan alat berat bergerak. Pajak kendaraan bermotor termasuk dalam kategori pajak langsung dan merupakan pajak daerah (daerah). Pajak kendaraan bermotor, yang dikelola oleh pemerintah sebagai pajak negara bagian, dimasukkan dalam sumber pendapatan yang dikirimkan ke setiap daerah.

Berdasarkan teori analisis implementasi kebijakan pemungutanPKB yang dilakukan kepada kantor UPTD WIlayah 1 SAMSAT Bandar Lampung, teori tersebut mengutip pandangan Edward III Subarsono (Ui, 2009):

1. Komunikasi, yaitu keberhasilan implementasi kebijakan, mengharuskan pelaksana mengetahui apa yang dilakuakan maksud dan tujuan kebiajakan wajib diteruskan kepada kelompok sasaran untuk mengurangi aturan dalam proses pelaksanaan. .

2. Sumber daya, meskipun isi kebijakan telah dikomunikasikan dengan jelas dan konsisten, namun jika pelaksana kekurangan sumber daya untuk melaksanakan kebijakan, pelaksanaannya tidak akan efektif. Sumber daya tersebut berupa sumber daya manusia, seperti kemampuan pelaksana dan sumber daya keuangan

3. Disposisi adalah karakter dan sifat pelaksana, seperti kejujuran, demokratis dan sifat komitmen. Dalam pelaksana ini memiliki temperamen baik, maka pelaksana dapat melaksanakan kebijakandiinginkan kepada pembuat kebijakan. Jika sikap atau pendapat pelaksana dan pengambil keputusan berbeda, proses implementasi kebijakan juga menjadi tidak valid.

4. Struktur Birokrasi yang bertanggung jawab atas implementasi kebijakan memiliki pengaruh yang signifikan terhadap implementasi kebijakan. Berbagai aspek struktur organisasi adalah prosedur operasi standar (SOP) dan fragmentasi. Struktur organisasi yang terlalu panjang akan memperlemah pengawasan dan 
mengarah pada birokrasi yaitu prosedur birokrasi yang rumit, dan membuat

\section{METODOLOGI}

Penulis penelitian ini menggunakan jenis penelitian deskriptif, yang bertujuan untuk menjelaskan atau medeskripsikan situasinya dan mencoba menjelaskan pemecahan masalah melalui metode kualitatif melalui data(Sugiyono, 2010). Penelitian ini penulis menggunakan jenis penelitian kualitatif, karena itu sesuai kebutuhan peneliti perlu memperoleh pemahaman yang komprehensif dan mendalam tentang analisis implementasi kebijakan pemungutan pajak kendaraan bermotor (PKB).dengan hal ini tidak hanya mendeskripsikan data tetapi juga ada beberapa teknik pengumpulanya data ini melalui observasi (pengamatan), dokumentasi dan interview.Data diperoleh dari kantor, buku (literatur), peraturan perundang-undangan, peraturan daerah, peraturan pemerintah atau pihak lain yang menyediakan data berkaitan erat dengan obyek dalam sebuah tujuan penelitian. Dalam penelitian ini peneliti memperoleh dokumen dari kantor UPTD Wilayah 1 SAMSAT Bandar Lampung.Informan dalam penelitian ini ialah a. Kepala bidang Uptd Wilayah 1 SAMSAT Kota Bandar Lampung b. 2 orang staf Samsat, c.2 orang Masyarakat .

\section{HASIL DAN PEMBAHASAN}

\section{Analisis Implementasi Pemungutan Pajak Kendaraan Bermotor (PKB) yang dilakukan oleh kantor UPTD Wilayah 1 SAMSAT Bandar Lampung}

Dalam pembahasan kali ini, penulis akan memaparkan bagaimana kantor SAMSAT Bandar Lampung di UPTD Kabupaten 1 menggunakan teori Edward III (Subarsono, 2011: 90-92) yaitu komunikasi, sumber daya, pembuangan, dan struktur birokrasi. Peran Pemungutan Pajak Kendaraan Bermotor (PKB) yang kegiatan organisasi menjadi tidak fleksibel.

dilaksanakan diKantor UPTD Wilayah 1 SAMSAT Bandar Lampung dapat dijelaskan dengan penjelasan sebagai berikut:

Dalam pembahasan kali ini, penulis akan memaparkan bagaimana kantor SAMSAT Bandar Lampung di UPTD Kabupaten 1 menggunakan teori Edward III (Subarsono, 2011: 90-92) yaitu komunikasi, sumber daya, pembuangan, dan struktur birokrasi. Peran Pemungutan Pajak Kendaraan Bermotor (PKB) yang dilaksanakan oleh diKantor UPTD Wilayah 1 SAMSAT Bandar Lampung dapat dijelaskan dengan penjelasan sebagai berikut:

\section{Komunikasi}

Komunikasi ini menunjukkan peranan sebagai acuan agar pelaksana kebijakan mengetahui persis apa yang akan mereka kerjakan. Ini berarti bahwa komunikasi juga dapat dinyatakan dengan perintah dari atasan terhadap pelaksana kebijakan sehingga penerapan kebijakan tidak keluar dari sasaran yang dikehendaki. Komunikasi yang tidak sempurna akan berdampak pada para pelaksana menafsirkan kebijakan sebagai otoritas, seperti tindakan-tindakan untuk menyempitkan kebijakan umum menjadi kebijakan spesifik. Berdasarkan hasil wawancara yang telah penulis lakukan menggunakan teori Edward III dengan metode komunikasi para implementator dan masyarakat hanya sebagian yang mengetahui informasi tentang berlakunya pembayaran pajak kendaraan bermotor (PKB) .

Dari hasil wawancara penulis lakukan dengan Kepala seksi Pendataan dan PenetapanUPTD Wilayah 1 SAMSAT Bandar Lampung mengungkapkan:

"proses komunikasi terjalin dengan baik antara pihak-pihak yang bekerja sama berdasarkan 
stakeholder kita kerja sama dengan pihak kepolisian, jasaraharja artinya kita ngambil pajak itu sebelum ditetapkan kan sudah ada keterkaitan kerjasama dengan stakeholder polri dengan jasaraharja" (wawancara tanggal 5 januari 2021).

Sementara itu menurut Staf UPTD Wilayah 1 SAMSAT Bandar Lampung)mengungkapkan :

"pada penyaluran informasi (tranmisi) yang diterima maupun disalurkan karena sejauh ini tidak ada kendala sebab ada breffing sebelum pembukaan operasional pelayanan, ada juga grup WA untuk para pegawai SAMSAT sehingga jika ada informasi yang mendesak bisa diberitahukan sebelumnya Pada kejelasan informasi bahwa sudah cukup konsistensi dan sebagian lainnya fleksibel. aspek komunikasi, untuk hal Konsistensi, bisa diantisipasi dengan mengacu kembali pada tupoksi masing-masing agar konsistensi komunikasi berjalan lancar sesuai dengan yang diharapkan. Dan tidak mengaburkan tujuan-tujuan informasi oleh pelaku kebijakan atas dasar kepentingan sendiri dengan cara mengintrepetasikan informasi berdasarkan pemahaman sendirisendiri." (wawancara tanggal 5 januari 2021).

Sementara Itu menurut Masyarakat Wajib Pajak mengungkapkan :

" untuk informasi yang kita dapat dalam implementasi pemungutan pajak ini berjalan dengan baik dengan adanya kegiatan sosilisasi untuk pemungutan pajak kendaraan bermotor selain itu juga untuk pembayaran pajak ini informasi yang bisa diambil bisa melalui samsat link dan samsat keliling sangat membantu untuk pembayaran pkb. (wawancara tanggal 5 januari 2021).

Berdasarkan kesimpulan yang peneliti ambil bahwa adanya kerja sama antar pihak kepolisian dan jasaraharja untuk pembayaran pajak dan untuk aspek komunikasi, dalam hal Konsistensi, bisa diantisipasi dengan mengacu kembali pada tupoksi masing-masing agar konsistensi komunikasi berjalan lancar sesuai dengan yang diharapkan. Dan tidak mengaburkan tujuan-tujuan informasi oleh pelaku kebijakan atas dasar kepentingan sendiri dengan cara mengintrepetasikan informasi berdasarkan pemahaman sendiri-sendiri.

\section{Sumber daya}

Sumber daya ini berkaitan dengan segala sumber yang digunakan untuk mendukung keberhasilan implementasi pemungutan pajak kendaraan bermotor (PKB) di kantor UPTD Wilayah 1 Bandar Lampung. Sumber daya ini mencakup sumber daya manusia, fasilitas, informasi dan kewenangan. Subjek penelitian mengatakan bahwa sumber daya berpengaruh terhadap pelaksanaan pemungutan pajak kendaraan bermotor (PKB).

Dari hasil wawancara penulis lakukan dengan Kepala Bidang UPTD Wilayah 1 SAMSAT Bandar Lampung mengungkapkan :

"untuk sumber daya manusianya sudah normal sudah baik artinya tinggal kita untuk lebih baik untuk pelayanan yang lebih baik, kalau untuk sumber daya finansialnya disini tidak ada, adanya dipihak bank lampung untuk sektor pajaknya sarana perasarananya sudah memadai semua hanya yang kurang memadai kadang-kadang sistem aja ya namnya internet kadang ada gangguan jaringan itupun gak rutin" (wawancara tanggal 5 januari 2021) 
Sementara itu menurut Staf UPTD Wilayah 1 SAMSAT Bandar Lampung) mengungkapkan :

"Pada kewenangan pegawai seperti Kepala Bagian maupun Kepala Seksi sangatlah berpengaruh pada aktivitas kerjanya. Sebab tanpa kewenangan maka sebagai pemimpin petunjuk arah seperti yang di insttruksikan bisa tidak sesuai dengan apa yang diharapkan akan tetapi perlu juga mengetahui batasbatas kewenangannya.pada indikator staff dalam sumberdaya implementasi kebijakan. Kegagalan yang sering terjadi dalam implementasi kebijakan, salahsatunya disebabkan oleh staf/pegawai yang tidak kompeten dalam bidangnya. Penambahan jumlah staf dan implementor saja tidak cukup menyelesaikan persoalan implementasi kebijakan, tetapi diperlukan sebuah kecukupan staf dengan keahlian dan kemampuan yang diperlukan (kompeten dan kapabel) dalam mengimplementasikan

kebijakan."(wawancara tanggal 5 januari 2021)

Sementara Itu menurut Masyarakat Wajib Pajak mengungkapkan :

"fasilitas di samsat bandar lampung sudah baik dan sebagai contoh penggunaan komputer dan Sistem Samsat Online yang secara cepat mengakses data apa saja yang diperlukan untuk melayani wajib pajak. Jika faktor-faktor yang mendukung dalam pemberian pelayanan kepada masyakat terpenuhi maka semua roda kegiatan pembangunan akan semakin lancar. (wawancara tanggal 5 januari 2021)

Berdasarkan kesimpulan peneliti bahwa Aspek sumber daya, pada indikator staff dalam sumberdaya implementasi kebijakan.fasilitas di samsat bandar lampung sudah baik dan sebagai contoh penggunaan komputer dan Sistem Samsat Online yang secara cepat mengakses data apa saja yang diperlukan untuk melayani wajib pajak. Kegagalan yang sering terjadi dalam implementasi kebijakan, salahsatunya disebabkan oleh staf/pegawai yang tidak kompeten dalam bidangnya. Penambahan jumlah staf dan implementor saja tidak cukup menyelesaikan persoalan implementasi kebijakan, tetapi diperlukan sebuah kecukupan staf dengan keahlian dan kemampuan yang diperlukan (kompeten dan kapabel) dalam mengimplementasikan kebijakan.

\section{3) Disposisi}

Jika implementasi kebijakan diharapkan berlangsung efektif, para pelaksana kebijakan tidak hanya harus mengetahui apa yang harus dilakukan dan memiliki kapabilitas untuk melaksanakan tetapi mereka juga harus mempunyai keinginan untuk melaksanakan kebijakan tersebut. Para pelaksana tidak selalu melaksanakan kebijakan sesuai dengan keinginan pembuat kebijakan. Akibatnya pembuat kebijakan sesuai sering berhadapan dengan tugas-tugas untuk memanipulasi atau bekerja dalam lingkungan disposisi para pelaksananya atau bahkan membatasi otoritasnya mencakup sikap pelakasananya atau bahkan membatasi otoritasnya. Mencakup sikap pelaksana para pegawai sudah melaksanakan tugasnya dengan efektif tanpa ada paksaan atau keberatan dalam melayani masyarakat.

Dari hasil wawancara penulis lakukan dengan Staf UPTD Wilayah 1 SAMSAT Bandar Lampung mengungkapkan bahwa:

"bahwa penting sekali pemahaman kerja (kognisi) pada ruang lingkup atau bidang kerjanya. Tanpa suatu kognisi maka pekerjaan menjadi terbengkalai. Dengan kognisi juga setiap lapisan pegawai bisa 
mengetahui sejauh mana batas-batas kerja yang bisa dilakukannya dan pada bagian mana bukan dari tugasnya."

Dari hasil wawancara penulis lakukan dengan Kepala Bidang UPTD Wilayah 1 SAMSAT Bandar Lampung mengungkapkan bahwa:

"Untuk kompensasi bagi beberapa Pegawai di Samsat khususnya ASN mengutarakan bahwa sudah seimbang dan sesuai dengan tugas kerja mereka. khususnya PTHL berpendapat belum seimbang atau sesuai dengan tugas kerjanya. Karena seringkali pegawai PTHL mendapat tugas kerja yang ganda. Pada aspek disposisi, insentif (kompensasi) merupakan salah-satu teknik yang disarankan untuk mengatasi masalah sikap para pelaksana kebijakan dengan memanipulasi insentif, maka memanipulasi insentif oleh para pembuat kebijakan mempengaruhi tindakan para pelaksana kebijakan."

Sama halnya pertanyaan tersebut menurut Masyarakat Wajib Pajak mengungkapkan :

"sikap pelaksana ini normal-normal saja artinya bila ada wajib pajak untuk peroses wajib pajak tahunan, bbn atau sebagainya bila mana registrasi dari pihak kepolisian sudah lengkap ya pasti peroses pajaknya sesuai nilai jual kendaraan bermotor kendaraan tersebut, lalu kalau masalah hambatannya itu kadang-kadang yang sering terjadi salah input data, salah input data yang dimaksut itu tipe kendaraannya, tahun pembuatannya cuman kan tidak telalu signifikan " (wawancara tanggal 5 januari 2021)

Berdasarkan kesimpulan bahwa peneliti meyakini bahwa pada aspek disposisi, insentif (kompensasi) merupakan salah-satu teknik yang disarankan untuk mengatasi masalah sikap para pelaksana kebijakan dengan memanipulasi insentif, maka memanipulasi insentif oleh para pembuat kebijakan mempengaruhi tindakan para pelaksana kebijakan. bahwa Insentif sebagai instrument dorongan pada seseorang agar mau bekerja dengan baik dan agar lebih dapat mencapai tingkat kinerja yang lebih tinggi sehingga dapat menambah kemauan kerja dan motivasi seorang pegawai agar terciptanya suatu kinerja yang berkualitas.

\section{4) Struktur Birokrasi}

Struktur Birokrasi merupakan Standar Oprasional Prosedur (SOP). Yang mengatur plaksanaan kebijakan. Secara umum kegiatannya menunjukan status secara relatif. Setruktur Birokrasi yang ada di Dispenda adalah setruktur yang secara umum mengatur hubungan baik dari Kepala Dinas ataupun Kepala Seksi. Berdasarkan Standar Oprasional Prosedur (SOP), Setruktur Birokrasi sejauh ini belum bisa dikatakan terealisasi, sehinga tidak adanya kejelasan antar jenjang Hirarki, Pelembagaan, Komunikasi, jaringan Informasi, Hubungan.

Dari hasil wawancara penulis lakukan dengan Selaku Kepala Seksi UPTD Wilayah 1 SAMSAT Bandar Lampung dengan pertanyaan:

"bahwa SOP merupakan hal yang sangat penting diterapkan pada suatu pekerjaan karena dengan adanya SOP monitoring kerja bisa terlaksana sesuai dengan tujuan yang diinginkan. Sementara sejauh mana kontrol SOP terhadap pelaksanaan tugas, sebagian informan menganggap bahwa sejauh ini kontrol SOP masih sangat fleksibel pada pelaksanaan tugas, sebab ukuran SOP hanya mengatur 
satu berkas, sementara setiap harinya pelayanan kami \pm 100 berkas yang dilaksanakan setiap harinya. Tentunya waktu tempuh yang dikerjakan akan berbeda."(wawancara tanggal 5 januari 2021).

Sama halnya menurut Staf UPTD Wilayah 1 SAMSAT Bandar Lampung : "justru dengan adanya SOP lah kontrol pada pelaksanaan tugas itu bisa berjalan. Pada fragmentasi seluruh pegawai berpendapat bahwa hal itu sangat dibutuhkan agar suatu pelayanan tidak terhambat jika terdapat anggota pelaksana yang berhalangan hadir. Ukuran dasar SOP atau prosedur kerja ini biasa digunakan untuk menanggulangi keadaan-keadaan umum diberbagai sektor publik dan swasta. Dengan menggunakan SOP, para pelaksana dapat mengoptimalkan waktu yang tersedia dan dapat berfungsi untuk menyeragamkan tindakan-tindakan pejabat dalam organisasi yang kompleks dan tersebar luas, sehingga dapat menimbulkan fleksibilitas yang besar dan kesamaan yang besar dalam penerapan peraturan." (wawancara tanggal 5 januari 2021).

Menurut kesimpulan yang diambil peneliti SOP merupakan hal yang sangat penting diterapkan pada suatu pekerjaan karena dengan adanya SOP monitoring kerja bisa terlaksana sesuai dengan tujuan yang diinginkan. Dengan menggunakan SOP, para pelaksana dapat mengoptimalkan waktu yang tersedia dan dapat berfungsi untuk menyeragamkan tindakan-tindakan pejabat dalam organisasi yang kompleks dan tersebar luas, sehingga dapat menimbulkan fleksibilitas yang besar dan kesamaan yang besar dalam penerapan peraturan.
Faktor-faktor yang mempengaruhi implementasi pemungutan pajak kendaraan bermotor (PKB) yang dilakukan dikantor UPTD Wilayah 1 SAMSAT Bandar Lampung

\section{Faktor- Faktor Yang Mendukung}

Faktor yang mendukung di dalam pemungutan PKB Di Kantor UPTD Wilayah 1 SAMSAT Bandar Lampungantara lain :

a. Aktif Melayani Wajib Pajak melalui SAMSAT Keliling

SAMSAT Keliling adalah sebuah kebijakan pelayanan pajak daerah yang bertujuan untuk memudahkannya wajib pajak keluar kepada kantor pelayanan pajak daerah. Dalam perihal ini, petugas pajak daerah akan menggunakan kendaraan khusus yang dilengkapi peralatan pelayanan untuk mengunjungi tempat-tempat yang mudah dijangkau wajib pajak. Mobil khusus ini menggunakan satelit untuk terhubung ke sistem yang ada di kantor pengolah data pusat.

b. Memudahkan Pembayaran wajib Pajak dari Jarak Jauh.

Guna memudahkan wajib pajak dalam membayar pajak, biro pajak daerah melakukan kemudahan lalu menggelar sistem pembayaran jarak jauh bernama Samsat Online National (SAMOLNAS). Didalam perihal semua Wajib Pajak dapat membayar diUPTD Wilayah 1 SAMSAT, tetapi pajak yang harus dibayar hanya berlaku sebelum WITA 12.00 .

Dalam wawancara penulis bersama Kepala Bidang UPTD Wilayah 1 SAMSAT BandarLampung :

"Guna terus meningkatkan pendapatan asli daerah, SAMSAT Bandar Lampung UPTD Kabupaten 1 terus berupaya melakukan inovasi untuk meningkatkan pajak kendaraan bermotor. Dan juga ada 3 inovasi sebuah pelayanannya yang unggul diSAMSAT Bandar 
Lampung pada UPTD 1 ialah proses dikelolanya STNK dengan sistem komputer, pelayanan informasi wajib pajak kepada sebuah sistem komputer dan pelayanan aktif kepada wajib pajak melalui mobile SAMSAT atau samsat link, SAMSAT Bandar Lampung di UPTD 1 juga telah melaksanakan pembayaran faktur. inovasi. Langkah inovatif yang dilakukan antara lain mengirimkan surat pemberitahuan kepada wajib pajak untuk mengingatkan wajib pajak otomotif agar memenuhi kewajiban sebagai wajib pajak. Selain itu, inovasi yang lain ialah "penertiban". Dalam hal ini dinas pendapatan pajak daerah bekerja sama dengan kepolisian dan menurunkan anggotanya untuk mengontrol jalan. Bahkan, petugas pajak akan meninjau Surat Keputusan Pajak Daerah (SKPD) kendaraan bermotor untuk membayar pajak Orang memiliki dan memungut pajak dari wajib pajak yang telah melewati batas waktu pajak dan wajib pajak yang telah melewati batas waktu pajak. untuk meningkatkannya kesadaran wajib pajak dalam bayar pajak tepat waktu." (wawancara tanggal 5 januari 2021)

\section{Faktor Penghambat}

a. Partisipasi Masyarakat masih kurang dalam pembayaran wajib pajak

Dengan pertumbuhan ekonomi Bandar Lampung, laju pertumbuhan kendaraan bermotor di Bandar Lampung mengalami sebuah peningkatan dalam beberapa tahun terakhir.Partisipasi Masyarakat masih kurang dalam pembayaran wajib pajak tepat waktu. Masyarakat harus mewaspadai pajak yang dipungut Retribusi dibayar dan siapa yang bisa dilihat dari hasil perpajakan. Pajak kendaraan yang dipungut dari pemilik kendaraan bermotor akan digunakan untuk pembangunan daerah dengan dasar pengelolaan yang baik untuk kemaslahatan masyarakat. Peran masyarakat dalam perpajakan sangat penting, pemerintah daerah tidak bisa bekerja sendiri karena pemerintah daerah dan masyarakat harus bekerjasama. Penting untuk membangun budaya pemahaman tentang pembayaran pajak mobil.

b. Sebuah Data Masyarakat Wajib Pajak yang tidak lengkap

Alamat dari wajib pajak tersebut seringkali memiliki data wajib pajak yang tidak lengkap. akan perihal ini, tidak terbayarnya wajib pajak dapat menyulitkan karyawan untuk menagih secara langsung. Data alamat untuk yang tidak lengkap ini terjadi disaat pendaftaran, antara lain salahnya pengetikan kepada petugas dan ketidakjelasan alamat kepada KTP Wajib Pajak. c. Pemindahtanganan Kendaraan
Bermotor tanpa di balik nama

Di UPTD wilayah 1 SAMSAT Bandar Lampung, pengalihan kendaraan bermotor tanpa nama juga menjadi kendala perpajakan. Ini akan terjadi jika wajib pajak baru tidak membayar pajak. Selain kerugian dari mereka yang namanya terdaftar sebagai pemilik mobil pertama yang tentunya akan ditagih langsung oleh petugas pajak, petugas pajak juga akan mengalami kesulitan lain dalam proses pencarian pemilik mobil kedua, yang biasanya terjadi pada transfer Wajib pajak pada paragraf kedua mengangkut kendaraan ke orang yang tidak kenal atau tidak memiliki alamat orang tersebut.

d. Pemilik tempat berpindah tempat tinggal

Dalam hal ini kendala masih ada pada pemungutan pajak, namun mereka mengabaikan kewajiban wajib pajak. perihal ini sulitnya petugas pajak untuk memungut pajak yang mana secara alami dan memilik dampak peningkatan tunggakan pajak otomotif. 
Faktor penghambat lain yang dikemukakan oleh Kepala Bidang UPTD Wilayah 1 SAMSAT BandarLampung :

"Dalam beberapa kasus, kendaraan wajib pajak mobil adalah kendaraan angsuran yang dibayar oleh kantor keuangan. Apabila ditariknya suatu kendaraan bermotor kepada pihak pemberi biaya tanpa adanya laporan kepada pemilik kendaraan bermotor atau kepada pihak pembiayaan itu sendiri menjadi suatu kendala, maka dapat terjadi permasalahan dalam perihal ini yaitu pada perpajakan sebelum kendaraan tersebut dipajak. ditarik melalui pembiayaan kendaraan Wilayah biro didaftarkan sebagai objek Pajak Kendaraan Bermotor sehingga kendaraan itu menjadikan tunggakan pajak kendaraan bermotor tanpa adanya pelaporan penarikan. maka karena itu, pemilik atau pemberi pembiayaannya harus laporkan perkara tersebut di tempat kendaraannya terdaftar sebagai objek pajak kendaraan." (wawancara tanggal 5 januari 2021)

\section{KESIMPULAN}

Berdasarakan uraian pada hasil penelitian dan pembahasan, maka penulis menarik kesimpulan sebagai berikut:

1. Berdasarakan hasil penelitian dan pembahasan yang penulis dapat, maka penulis dapat mengambil kesimpulan yaitu sebagai berikut:Menurut apa yang diamati peneliti, bahwa mekanisme pelaksanaan kebijakan ini sudah cukup efektif ada beberapa indikator dalam penelitian ini yaitu: Komunikasi,adanya kerja sama antar pihak kepolisian dan jasaraharja untuk pembayaran pajak dan untuk aspek komunikasi, dalam hal Konsistensi, bisa diantisipasi dengan mengacu kembali pada tupoksi masing-masing agar konsistensi komunikasi berjalan lancar sesuai dengan yang diharapkan. Dan tidak mengaburkan tujuan-tujuan informasi oleh pelaku kebijakan atas dasar kepentingan sendiri dengan cara mengintrepetasikan informasi berdasarkan pemahaman sendirisendiri.(b) Sumber Daya,fasilitas di samsat bandar lampung sudah baik dan sebagai contoh penggunaan komputer dan Sistem Samsat Online yang secara cepat mengakses data apa saja yang diperlukan untuk melayani wajib pajak. Kegagalan yang sering terjadi dalam implementasi kebijakan, salah-satunya disebabkan oleh staf/pegawai yang tidak kompeten dalam bidangnya. Penambahan jumlah staf dan implementor saja tidak cukup menyelesaikan persoalan implementasi kebijakan, tetapi diperlukan sebuah kecukupan staf dengan keahlian dan kemampuan yang diperlukan (kompeten dan kapabel) dalam mengimplementasikan kebijakan.

(c) Disposisi, insentif (kompensasi) merupakan salah-satu teknik yang disarankan untuk mengatasi masalah sikap para pelaksana kebijakan dengan memanipulasi insentif, maka memanipulasi insentif oleh para pembuat kebijakan mempengaruhi tindakan para pelaksana kebijakan. bahwa Insentif sebagai instrument dorongan pada seseorang agar mau bekerja dengan baik dan agar lebih dapat mencapai tingkat kinerja yang lebih tinggi sehingga dapat menambah kemauan kerja dan motivasi seorang pegawai agar terciptanya suatu kinerja yang berkualitas.(d) Struktur Birokrasi,SOP merupakan hal yang sangat penting diterapkan pada suatu pekerjaan karena dengan adanya SOP monitoring kerja bisa terlaksana sesuai dengan tujuan yang diinginkan. Dengan menggunakan SOP, para pelaksana dapat mengoptimalkan waktu yang tersedia dan dapat berfungsi untuk menyeragamkan tindakan-tindakan 
pejabat dalam organisasi yang kompleks dan tersebar luas, sehingga dapat menimbulkan fleksibilitas yang besar dan kesamaan yang besar dalam penerapan peraturan.

2. Faktor-faktor yang mendukung penerapan PKB oleh kantor UPTD Wilayah 1 SAMSAT Bandar Lampung antara lain yaitu:

1. Sumber daya manusia (SDM) yang memadai

2. Aktif Melayani Wajib Pajak melalui SAMSAT Keliling

3. memudahkan Pembayaran wajib Pajak dari Jarak Jauh

3. Faktor-faktor yang menghambat penerapan PKB oleh kantor UPTD Wilayah 1 SAMSAT Bandar Lampung:

1. Kesadaran masyarakat terhadap kinerja wajib pajak terhadap kewajiban perpajakannya masih rendah

2. Informasi wajib pajak tidak lengkap

3. Mengendarai kendaraan bermotor tanpa nama secara manual

4. Pemilik pindah ke area lain
5. Menarik kendaraan bermotor dari penggalangan dana tanpa ada laporan dari pemilik kendaraan bermotor atau pihak pembiayaan itu sendiri.

6. Banyaknya peraktek pencaloan.

\subsection{SARAN}

Saran penulis saat menulis Penulisan Skripsi ini yaitu:

1. Wajib dibangunnya kesadaran di antara semua wajib pajak supaya dapat disiplin dalam melakukan atau melaksanakan kewajiban perpajakannya

2. Petugas perpajakan dalam perihal ini Dinas Pajak Propinsi Lampung supaya memiliki kontrol yang lebih terhadap Wajib Pajak yang tidak pernah mendapat tindakan disipliner dalam melaksanakan kewajiban perpajakannya.

3. Meningkatkan pendapatan asli daerah dengan cara terus mencari sebuah inovasi di dinas pajak kendaraan bermotor. 


\section{DAFTAR PUSTAKA}

Andhini, N. F. (2017). Evaluasi Implementasi Kebijakan Publik (Studi Kasus: Evaluasi Implementasi Kebijakan Un Sd Di Kota Madya Jakarta Pusat). Journal of Chemical Information and Modeling, 53(9), 1689-1699.

Puji Rahayu, SE, M. (2019). perpajakan disesuaikan dengan peraturan perpajakan terbaru (C. Jeni Susyanti, SE., M.M., BKP. (ed.)). Indomedia Pustaka.

Rushananto. (2014). Kebijakan Publik. Kebijakan Publik, 1993, 15.

Sugiyono, P. D. (2010). METODE PENELITIAN ADMINISTRASI (S. T. Apri Nuryanto, S.Pd. (ed.)). ALFABETA, CV.

Ui, F. (2009). Analisis implementasi..., Dwi Nurani, FISIP UI, 2009.

William N. Dunn. (1999). William-N.-Dunn-Pengantar-Analisis-Kebijakan-Pulblik-GadjahMada-University-Press-2003_compressed-1.pdf (p. 710).

Undang-Undang Nomor 22 Tahun 2009 tentang Lalu Lintas Dan Angkutan Jalan mengatur bahwa setiap kendaraan bermotor akan melaju di jalan raya harus di lengkapi dengan Surat Tanda Nomor Kendaraan (STNK) dan Tanda Pengenal Kendaraan Bermotor (TNKB).

Undang-Undang Nomor 28 Tahun 2009 tentang Pajak Kendaraan Bermotor 